\title{
EVALUATION OF Chlorella vulgaris PRODUCTION AS FUCTION OF GLYCEROL AND CORN STEEP LIQUOR CONCENTRATION USING FACTORIAL DESIGN
}

\author{
P.E.C. SILVA ${ }^{1}$, F.A.S.D. de SOUZA ${ }^{2}$, D.A.V. MARQUES ${ }^{2}$, A.L.F. PORTO ${ }^{2}$, R.P. \\ BEZERRA $^{2}$ \\ ${ }^{1}$ Universidade Federal de Pernambuco, Laboratório de Imunopatologia Keizo Azami. \\ ${ }^{2}$ Universidade Federal Rural de Pernambuco, Departamento de Morfologia e Fisiologia \\ Animal \\ E-mail para contato: rpbezerra@yahoo.com.br
}

RESUMO - Microalgae are potential sources of high value chemicals and bioactive compounds. To promote the cell productivity, culture conditions such as carbon and nitrogen sources, irradiance, temperature, bioreactor design have been investigated. Under mixotrophic conditions, some microalgae grows rapidly and to have a higher growth rate when compared to photoautotrophic conditions. This works reports Chlorella vulgaris production under mixotrophic conditions using glycerol and corn steep licor. The factorial design $\left(2^{2}\right.$ plus star central) was performed with $0.5-1.5 \%$ gycerol $\left(C_{g l y}\right)$ and $0.5-1.5 \%$ corn steep liquor $\left(C_{c s l}\right)$ using maximum cell concentration $\left(X_{\mathrm{m}}\right)$, cell productivity $\left(P_{\mathrm{X}}\right)$ as response. Results from the response surface methodology were that the $X_{\mathrm{m}}$ of $1.52 \mathrm{~g} \mathrm{~L}^{-1}$ was obtained using $0.9 \%$ of $G$ and $1.2 \%$ of $C S L$. The highest $P_{\mathrm{X}}$ value was $232 \mathrm{mg} \mathrm{L}^{-1}$ day ${ }^{-1}$ with $1.5 \%$ of $G$ and $C S L$. Therefore, these models can be useful to predict maximum cell concentration in mixotrophic cultures.

\section{INTRODUÇÃO}

Microalgae biomass production is of great interest in the search for nutraceutical and pharmaceutical purposes or for a sustainable feedstock for the production of biodiesel. It has mainly been achieved by autotrophic cultivation. However, autotrophic cultivation is often limited by light deficiency caused by mutual shading of cells, and biomass yield in these cultures is too low to promote applications of the microalgae. A feasible alternative is to use a mixotrophic culture in which such as carbon sources and $\mathrm{CO}_{2}$ in the presence of light are simultaneously assimilated and both respiratory and photosynthetic metabolism operates concurrently. Microalgae have also shown the potential to reduce emerging environmental problems, such as the greenhouse effect and industrial water pollution.

Medium composition, especially carbon and nitrogen sources, is one of the critical factor for the growth of microalgae (Perez-Garcia et al., 2011; O'Grady, et al., 2010). Effects of different types of carbon and nitrogen sources and their concentrations on biomass from certain species of Chlorella have been investigated previously (Gautam et al., 2013; CerónGarcía et al., 2013; Ramanna et al., 2014). Therefore, to obtain higher biomass, it is important to find appropriate types of carbon and nitrogen sources and their optimum concentrations in growth medium of $C$. vulgaris which is a promising microalga to be used as a source of biomass. 
Previous research showed that $C$. vulgaris have some potential to utilize glycerol, the by-products of the biodiesel industry, and agro-industrial co-products, such as soy whey, as their carbon sources to accumulate the biomass (Gautam et al., 2013; Mitra et al 2012).

Although, the biomass productivities are significantly higher with mixotrophic growth compared with autotrophic growth (Chojack et al., 2004), it is also important to consider the cost of nitrogen and carbon sources for developing cost effective microalgal production (Perez-Garcia, et al., 2011). Published reports indicate that media components used add significant cost to the production, and it may even reach up to $30 \%$ of the total production cost (Miller and Churchill, 1986). Therefore, it is utmost important to find cheap substrates for microalgae production which will make the process economically viable.

The combination of microalgae cultivation with industrial waste would make the production of microalgae more economically viable (Pittman et al., 2011). To overcome high substrate costs, cheap resources should be found. Glycerol which is a by-product of biodiesel production can be used to $C$. saccharophila and $C$. vulgaris growth which allows for reducing the cost of carbon source used (Isleten-Hosoglu et al., 2012; Raí et al., 2013).

In order to improve the biomass production and subsequently decrease the cost of this biotechnological process, studies have been performed by optimizing the culture conditions. In this paper, we are focusing on mixotrophic cultures of $C$. vulgaris, using glycerol and corn steep liquor to obtain the maximum cell productivity. To simplify the process of the experiments, the method of Box-Behnken Design was adopted, which has been used in microalgae production optimization (Patil et al., 2011).

\section{MATERIAL AND METHODS}

\subsection{Microalgae and media}

C. vulgaris (UTEX 1803) was obtained from the UTEX (University of Texas, Austin). Cultures were maintained axenically in liquid Bold's Basal medium (Bischoff and Bold, 1963) which was suggested by University of Texas Culture Collection.

The culture medium, except the organic substrates, was sterilized in an autoclave at $121{ }^{\circ} \mathrm{C}$ for $20 \mathrm{~min}$. Corn steep liquor was treated according to Liggett and Koffler (1998). The organic nutrients such as glycerol and treated corn steep liquor were separately sterilized in different bottles in an autoclave at $121{ }^{\circ} \mathrm{C}$ for $20 \mathrm{~min}$ and aseptically added into the medium.

\subsection{Culture conditions}

C. vulgaris was grown mixotrophically on $400 \mathrm{~mL}$ of sterile culture media (initial $\mathrm{pH}$ of 6.8) in 1000-mL Erlenmeyer flasks at $27 \pm 1{ }^{\circ} \mathrm{C}$, under a constant fluorescent light intensity of approximately $74 \mu \mathrm{mol}$ photons $\mathrm{m}^{-2} \mathrm{~s}^{-1}$ measured by a LI-250 Light Meter with a LI-190 quantum sensor (LI-COR, USA). Agitation during cell growth was provided by sparging air. Inital cell concentration was $50 \mathrm{mg} \mathrm{l}^{-1}$ for all the cultivation conditions. The medium was supplemented with glycerol and corn steep liquor (Corn Products Brazil, Cabo - PE, Brazil) as described in Table 1. Periodic samples were taken from the flasks to determine the cell density, which were then used to calculate the biomass productivities. 


\subsection{Determination of cell dry weight and optical density}

Cell concentration (optical density) was estimated by absorbance of the suspension at $685 \mathrm{~nm}(\mathrm{Xu}, 2008)$ with a UV-vis spectrophotometer. A calibration curve between optical density and cell dry weight was developed by filtering the aliquots on pre-weighed GF/C filter paper. The filtered cells were dried at $105^{\circ} \mathrm{C}$ until constant weight was obtained and cooled to room temperature in a desiccator before weighing.

\subsection{Determination of cell productivity}

Biomass productivity $(\mathrm{Px}, \mathrm{g} / \mathrm{L} \mathrm{d})$ during $\mathrm{Tx}$ culture period was calculated from the Equation 1, where $\mathrm{Xt}$ was the biomass concentration $(\mathrm{g} / \mathrm{L})$ at the end of the exponential growth phase (tx) and $\mathrm{X} 0$ the initial biomass concentration $(\mathrm{g} / \mathrm{L})$ at $\mathrm{t} 0$ (day):

$P_{x}=\frac{X_{t}-X_{0}}{T_{x}-T_{0}}$

\subsection{Experimental design and data analysis}

Response surface methodology (RSM) designs such as Box-Behnken and Central Composite Design (CCD) model probable curvature of the response function. A 2-factor, 2level design is suitable for exploring quadratic response surfaces and constructing second order polynomial models (Equation 2) by using the Statistical software (version 8.0, Statistic Inc., Minneapolis, MN).

$Y=b_{0}+\sum b_{i} x_{i}+\sum b_{i i} x_{i i}^{2}+\sum b_{i j} x_{i} x_{j}$

Were, $\mathrm{Y}$ is the response function, $b_{0}$ is an intercept, $\mathrm{b}_{\mathrm{i}}, \mathrm{b}_{\mathrm{ii}}$ and $\mathrm{b}_{\mathrm{ij}}$ are the coefficients of the linear, quadratic and interaction terms, respectively. And accordingly $X_{\mathrm{i}}$ and $X_{\mathrm{j}}$ represent the coded independent variables. The fitted polynomial equation is expressed as surface plots in order to visualize the relationship between the response and experimental levels of each factor and to deduce the optimum conditions.

The data apart from optimization experiments were analyzed one-way analysis of variance (ANOVA) and Tukey's test. All used statistics were based on a confidence level of $95 \%$.

\section{RESULTS AND DISCUSSION}

\subsection{Growth profiles of the $C$. vulgaris microalgae under effects of $C_{\text {gly }}$ and $C_{c s l}$}


Growth profiles of the C. vulgaris microalgae with $1 \%$ glycerol and different CSL concentrations are showed in Figure 1. Increasing corn steep liquor concentration increases the $X_{\mathrm{m}}$. In mixotrophic microalgae culture, the metabolism assimilates $\mathrm{CO}_{2}$ autotrophic and organic sources provided to it. According to the literature, some microalgae show much higher yield when cultivated mixotrophically which can be justified by the fact that the additional carbon source minimizes the consequences generated by self-shading effect. The assimilation of inorganic carbon is hampered due to high cell density, due to low light availability. When microalgae assimilate more carbon, have a higher production of carbohydrates, lipids and proteins.
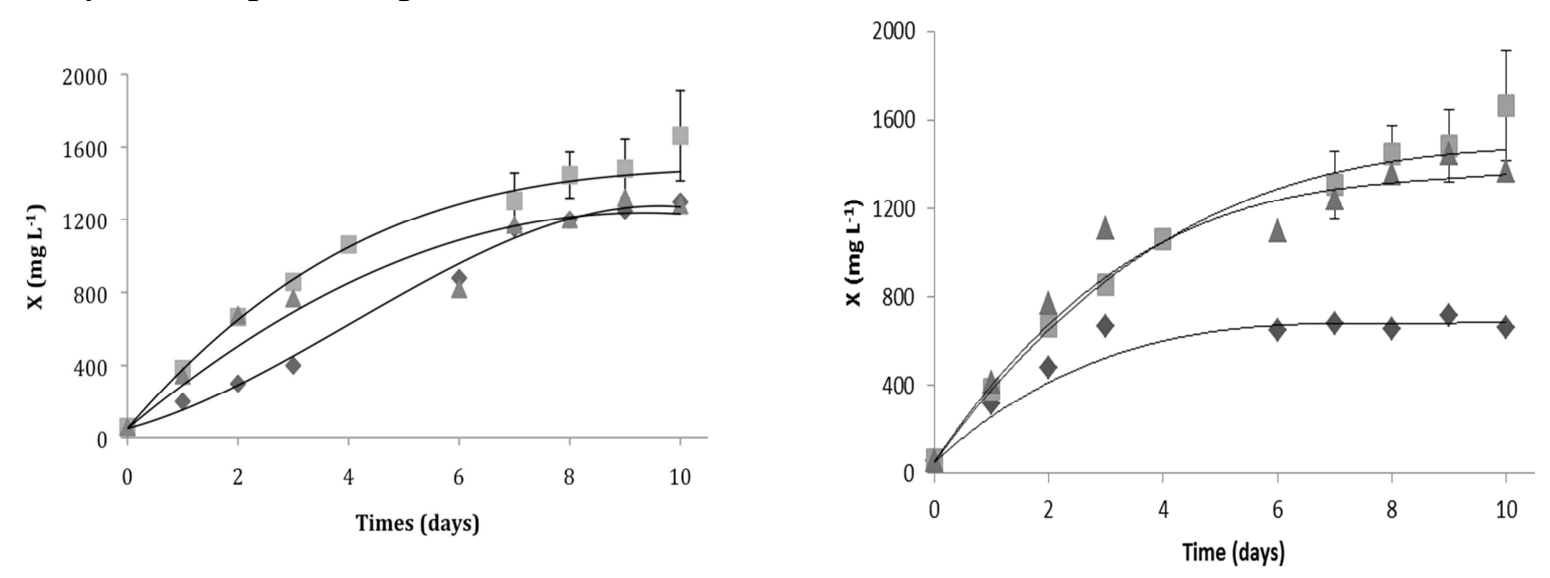

Figure 1 - (A) Growth profile of the microalgae $C$. vulgaris using $1 \%$ glycerol and differents

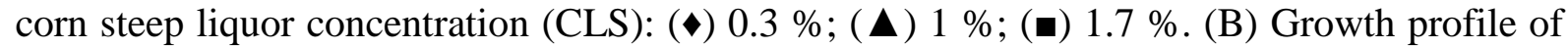
the microalgae $C$. vulgaris using $1 \%$ corn steep liquor and differents glycerol concentration:. (४) $0.3 \% ;(\mathbf{\square}) 1 \% ;(\boldsymbol{\Delta}) 1.7 \%$.

Corn steep liquor is rich in protein, carbohydrates, and minerals, and the above results showed that the nutrients were adequate for cell growth. When growth becomes limited due to nutritional deficiency or shading effect, the microalgae utilize the organic carbon source, such as corn steep liquor, in its metabolic processes or to have altered them to produce enzyme as protease, so that they were detectable by the assay procedure. The cultures with $0.3 \%$ and 1.7 $\%$ of $C_{c s l}$ showed similar cell concentration, with a slight decrease of approximately $18 \%$ when compared with $1 \%$ of $C_{c s l}$ (Fig. 1A). Stationary phase of growing using $0.3 \% C_{c s l}$ was after 5 days, obtained $X_{\mathrm{m}}$ of $650 \mathrm{mg} \mathrm{L}^{-1}$. In cultures with $1 \%$ of $C_{c s l}, X_{\mathrm{m}}$ was $1,455 \mathrm{mg} \mathrm{L}^{-1}$ after 8 days, while that using $1.7 \% C_{c s l}, X_{\mathrm{m}}$ was $1,260 \mathrm{mg} \mathrm{L}^{-1}$ after 6 days. $C$. vulgaris growth using $1 \%$ glycerol and $1 \% C_{c s l}$ obtained highest cell concentration and can be quite viable when applied on an industrial scale. Mahboob et al. (2012) related that corn steep liquor and urea, which are low cost nitrogen sources, were highly stable for C.vulgaris growth.

The growth profile of the C. vulgaris cultivates in BBM with $1 \% C_{c s l}$ and $1.7 \%$ glycerol exhibited an inhibitory effect on the growth of microalgae (Figure 1B). Konh et al. (2012) showed that Chlorella vulgaris can utilize glycerol as a sole carbon substrate for the production of biomass and biochemical components, such as photosynthetic pigments, lipids, soluble carbohydrates and proteins. The stationary phase of cell growth cultivated in $0.3 \%$ glycerol was obtained after 9 days and $X_{\mathrm{m}}$ values were of $1,250 \mathrm{mg} \mathrm{L}^{-1}$. When $C$. vulgaris was cultivated in BBM with $1 \%$ and $1.7 \%$ glycerol, the stationary phase reached after 8 days and $X_{\mathrm{m}}$ was of 1,455 and $1,200 \mathrm{mg} \mathrm{L}^{-1}$, respectively. 


\subsection{Optimizaton of and $C_{\mathrm{gly}}$ and $C_{c s l}$ concentrations on $\mathrm{Xm}$}

Response surface methodology is an approach that combines various statistical and mathematical techniques, and is useful for developing, improving and optimizing a process (Mandenius and Brundin, 2008). In the present study, Box-Behnken model for two variables (glycerol and $C_{c s l}$ ), along with their low, medium and high levels, was used as the experimental design model for optimization of mixotrophic growth of $C$. vulgaris. According to the implemented design, nine combinations were performed. In the experimental design model, $C_{c s l}(0.5-1.5 \%)$ and $G(0.5-1.5 \%)$ were taken as input variables. Cell concentration $(\mathrm{mg} / \mathrm{L})$ and cell productivity $(\mathrm{mg} / \mathrm{L} / \mathrm{d})$ were taken as a response of the system (Table 1$)$.

Table 1 - Experimental range and levels of the independent variables glycerol $\left(C_{\mathrm{gly}}\right)$ and corn steep liquor $\left(C_{C S L}\right)$ and Box-Behnken plan in actual value response $\left(X_{\mathrm{m}}, P_{\mathrm{X}}\right)$

\begin{tabular}{rcccccc}
\hline Test & $\mathrm{X}_{1}{ }^{\mathrm{a}}$ & $\mathrm{X}_{2}{ }^{\mathrm{b}}$ & $\begin{array}{c}C_{\mathrm{gly}}{ }^{\mathrm{c}} \\
(\%)\end{array}$ & $\begin{array}{c}C_{\mathrm{CSL}}{ }^{\mathrm{d}} \\
(\%)\end{array}$ & $X_{\mathrm{m}}{ }^{\mathrm{e}}\left(\mathrm{mg} \mathrm{L}^{-1}\right)$ & $\begin{array}{c}P_{\mathrm{X}}{ }^{\mathrm{f}}\left(\mathrm{mg} \mathrm{L}^{-1}\right. \\
\left.\mathrm{dia}^{-1}\right)\end{array}$ \\
\hline 1 & -1 & -1 & 0.5 & 0.5 & 881.2 & 146.0 \\
2 & -1 & 1 & 0.5 & 1.5 & 1325 & 220.0 \\
3 & 1 & -1 & 1.5 & 0.5 & 680.7 & 75.00 \\
4 & 1 & 1 & 1.5 & 1.5 & 1165 & 232.0 \\
5 & 1.414 & 0 & 1.7 & 1.0 & 1200 & 150.0 \\
6 & -1.414 & 0 & 0.3 & 1.0 & 1250 & 139.0 \\
7 & 0 & 1.414 & 1.0 & 1.7 & 1260 & 213.0 \\
8 & 0 & -1.414 & 1.0 & 0.3 & 650.0 & 130.0 \\
9 & 0 & 0 & 1.0 & 1.0 & 1430 & 179.0 \\
10 & 0 & 0 & 1.0 & 1.0 & 1480 & 185.0 \\
11 & 0 & 0 & 1.0 & 1.0 & 1430 & 179.0 \\
12 & 0 & 0 & 1.0 & 1.0 & 1480 & 185.0 \\
\hline \\
= variable coded for $C_{\mathrm{gly}}{ }^{\mathrm{b}} \mathrm{X}_{2}=$ variable coded for $C_{\mathrm{CSL}}{ }^{\mathrm{c}} C_{\mathrm{gly}}=$ glycerol concentration $(\%) ;$ \\
CSL corn steep liquor concentration $(\%) ;{ }^{\mathrm{e}} X_{\mathrm{m}}=$ maximum biomass concentration; ${ }^{\mathrm{f}} P_{\mathrm{X}}=$ \\
productivity.
\end{tabular}

As showed in the Table $1, X_{\mathrm{m}}$ varied between 650.0 to $1,480 \mathrm{mg} \mathrm{L}^{-1}$. Based in these values, the regression analysis was applied to $X_{\mathrm{m}}$ in function of both $C_{\mathrm{gly}}$ and $C_{\mathrm{CSL}}$. It is possible to get a quadratic polynomial equation, derived from Equation (2), to express the relationship between $X_{\mathrm{m}}$ and the selected independent variables. To get better fitting of the model, the interaction coefficients between the independent variables were omitted, because they were proved to be not significant. The optimal conditions to maximize $X_{\mathrm{m}}\left(C_{\mathrm{gly}}=0.9 \%\right.$; $C_{\mathrm{CSL}}=1.2 \%$ ) were estimated by deriving Equation (2). The maximum cell concentration estimated by the model was $1,516 \mathrm{mg} \mathrm{L}^{-1}$. Li et al. (2011) using $0.1 \%$ glycerol in photoheterotrophic cultivation of $C$. minutissima UTEX 2341, achieved a maximum cell concentration of $770 \mathrm{mg} \mathrm{L}^{-1}$ in 7 days of culture. Liang et al. (2009) noted that the growth of C. vulgaris under autotrophic conditions yielded $722 \mathrm{mg} \mathrm{L}^{-1}$ of algal biomass in 6 days of culture. Carbon, nitrogen and phosphorous sources are three main influencing important nutrients microalgae growth (Chen and Chen, 2006), and use of glycerol as a carbon source strongly stimulate its growth. About $45 \%$ of microalgae organism is composed of carbon 
(Singh et al., 2011). The present work presented about twice the $X_{\mathrm{m}}$ obtained by Li et al. (2011) and Liang et al. (2009), demonstrating that the use of glycerol and corn steep liquor, an agro-industrial waste improve maximum cell concentration.

A second order polynomial model wherein the interaction terms have been fitted to the experimental data obtained from the Box-Behnken model experiment can be stated in the form of the following Equation 3:

$X_{m}=1448-53.9 C_{g l y}+273.6 C_{c s l}-114.1 C_{g l y^{2}}-316.6 C_{c s l^{2}}$

where $Y$ is the predicted response, i.e. the cell concentration $(\mathrm{g} / \mathrm{L})$, and $X_{1}$ and $C_{c s l}$ are the coded values.

The statistical significance of the model equation was evaluated by analysis of variance (ANOVA), which showed that the regression is statistically significant at $97 \%$ ( $p<$ $0.05)$ confidence level. The adjust coefficient of determination $\left(\mathrm{R}^{2}\right)$ was calculated to be 0.95 , indicating that the model could explain $95 \%$ of the variability.

Three-dimensional response surfaces were plotted on the basis of the model equation, to investigate the interaction among the variables and to determine the optimum concentration of each factor for maximum cell concentration. The maximum cell concentration was occurred when $\mathrm{G}$ and $C_{c s l}$ were at 0.9 and $1.2 \%$, respectively (Fig. 3A).
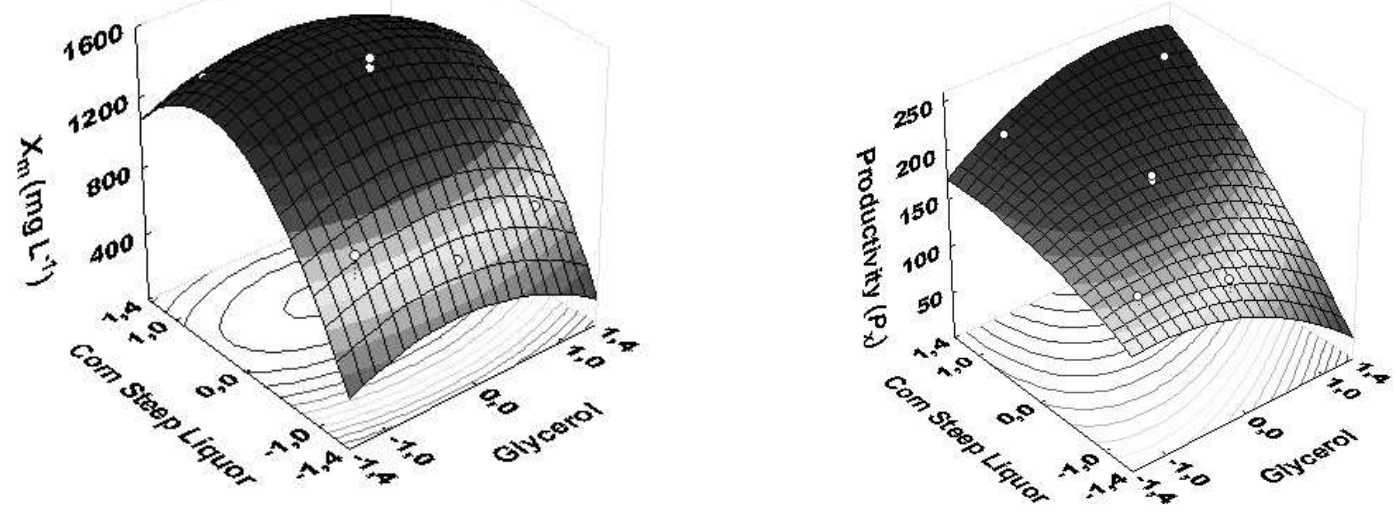

Figure 3 - Response surfaces showing the mutual effect of glycerol $\left(C_{\mathrm{gly}}\right)$ and corn steep liquor concentrations $\left(C_{c s l}\right)$ in maximum cell concentration $(\mathrm{A})$ and cell productivity $(\mathrm{B})$.

Likewise, glycerol uptake for some Chlorella species has been described in other studies. For example, simultaneous utilization of multiple organic substrates, glycerol, glucose and B. peptone by Chlorella saccharophila was reported by Isleten-Hosoglu et al., (2012), where $C$. saccharophila was capable of utilizing glycerol as a carbon source but its cell growth on glucose is much better than that on glycerol.

\subsection{Optimizaton of $C_{\mathrm{gly}}$ and $C_{c s l}$ concentrations on $C$. vulgaris productivity}


High $C_{\text {gly }}$ and $C_{c s l}$ increase cell productivity, obtaining higher values about $232 \mathrm{mg} \mathrm{L}^{-1}$ day $^{-1}$ (Table 1; Figure 2B). This result was obtained since there was a decrease in the cultivation time in the experiment with high $C_{\mathrm{gly}}$ and $C_{\mathrm{CSL}}$. By the way, cell productivity is calculated as function of cell concentration $\left(X_{\mathrm{m}}\right)$ and time cultivation, low time of cultivation provides higher cell productivity. Li et al. (2011) related that $C$. minutissima UTEX 2341 productivity of $110 \mathrm{mg} \mathrm{L}^{-1}$ day $^{-1}$ was obtained by addition of $1 \mathrm{~g} \mathrm{~L}^{-1}$ of glycerol, photoheterotrophic culture would also contributes to dramatic biomass increase. This study with $C$. vulgaris UTEX 18033 obtained cell productivity in little more than $50 \%$ compared with Li et al. (2011). Cheng et al. (2013) obtained C. protothecoides productivity of $108 \mathrm{mg}$ $\mathrm{L}^{-1}$ day $^{-1}, 50 \%$ lower than the present work, using $0.25 \mathrm{~g} \mathrm{~L}^{-1}$ proteose, a product of hydrolysis of proteins, which increases the cost of cultivation of microalgae. O'Grady and Morgan (2010) reported higher biomass productivity values for $C$. protothecoides on glucose and glycerol.

The second order polynomial equations (expressed in terms of coded values) fitted to the experimental data of the CCD for predicting $P x$, which showed $p$-value $<0.05$ are given in Equation (4).

$P_{x}=182.9-5.4 C_{g l y}+46.5 C_{c s l}-15.0 C_{g l y^{2}}-7.7 C_{c s l^{2}}+20.7 C_{g l y} C_{c s l}(4)$

The goodness of fit of the regression equation is tested by examining the adjusted determination coefficient, $\mathrm{R}^{2}$ Adj. The values $\mathrm{R}^{2}$ Adj $(0.80$ for Eqs.(4)) indicate a high degree of agreement between the observed and predicted values for cell productivity, suggesting that the proposed model equations provide satisfactory and accurate results.

Statistical testing of the model was conducted in the form of analysis of variance (ANOVA), which is required to assess the significance and adequacy of the model. Here, the ANOVA of the regression model demonstrates that the model is highly significant, as indicated by the calculated $p$-value $\leq 0.05$ for cell productivity.

\section{CONCLUSÃO}

These results demonstrate that mixotrophic $C$. vulgaris growth was capable of obtain high cell concentration e cell productivity using simultaneamente glycerol and corn steep liquor. Statistical methodology employed in this study resulted in a better understanding of the nutritional requirements for optimum growth of mixotrophic cultures of C. vulgaris. In general, the mutual effects of glycerol with corn steep liquour on cell dry weight were found by optimization of medium components. Also, high glycerol or corn steep liquor concentrations inihited the growth of $C$. vulgaris.

\section{REFERENCIAS}

BISCHOFF H. W.; BOLD H. C. Phycological Studies IV. Some Soil Algae from Enchanted Rock and Related Algal Species,. University of Texas Publication No. 6318, 1963, p. 95.

BOX, G.E.P.; BEHNKEN. D.W. Some new three level designs for the study of quantitative variables.Technometrics, v. 2, p.455-475, 1960. 


\section{9 a 22 de outubro de $2014^{8}$ \\ Florianópolis/SC}

CHEN, G.Q.; CHEN, F. Growing phototrophic cells without light. Biotechnol. Lett. v.28, p.607-611, 2006.

CHENG, K.C.; REN, M.; OGDEN, K.L Statistical optimization of culture media for growth and lipid production of Chlorella protothecoides UTEX 250. Biores Biotech v.128, p.44-48, 2013.

CHOJNACKA, K.; MÁRQUEZ-ROCHA, F.J. Kinetic and Stoichiometric Relationships of the Energy and Carbon metabolism in the Culture of Microalgae. Biotech., v.3, p.21-32, 2004. GAUTAM, K.; PAREEK,A.; SHARMA, D.K. Biochemical composition of green alga Chlorella minutíssima in mixotrophic cultures under the effect of different carbon sourcesJ.Biosc. Bioeng., v. 116 (5), p. $624-627,2013$

HEREDIA-ARROYO, T.; WEI, W.; HU. B. Oil accumulation via heterotrophic/mixotrophic Chlorella protothecoides Appl. Biochem. Biotechnol., v.162, p. 1978-199, 2010.

ISLETEN-HOSOGLU, M., GULTEPE, I., ELIBOL, M. Optimization of carbon and nitrogen sources for biomass and lipid production by Chlorella saccharophila under heterotrophic conditions and development of Nile red fluorescence based method for quantification of its neutral lipid content. Bioch. Eng. J., v.61, p. 11-19, 2012.

KONH, W.B.; YANG, H.; CAO, Y.T.; SONG, H.; HUA, F.; XIA, C. Effect and glycerol and glucose on the enhancement of biomass, lipid and soluble carbohydrate production by Chlorella vulgaris in mixotrophic culture. Food Technol. Biotechnol. v.51, p.62-69, 2012.

LI, Z.; YUAN, H.; YANG, J.; LI. B.Optimization of the biomass production of oil algae Chlorella. minutissima UTEX2341. Bioresour. Technol., v.102, p. 9128-9134, 2011.

LIANG, Y.; SARKANY, N.; CUI, Y. Biomass and lipid productivities of Chlorella Vulgaris under autotrophic, heterotrophic and mixotrophic growth conditions. Biotechnol. Lett. v.31, p. 1043-1049, 2009.

LIGGETT, R.W.; KOFFLER, H. Corn steep liquor in microbiology. Lafayet University. v.12 U.S.A. (1998)

MILLER T.L.; CHURCHILL, B.W. Substrates for large-scale fermentations In: A.L. Demain, L.A. Solomon (Eds.), Manual of industrial microbiology and biotechnology, American Society for Microbiology, Washington, DC (1986).

MITRA, D.; VAN LEEUWEN, J.; LAMSAL, B.Heterotrophic/mixotrophic cultivation of oleaginous Chlorella vulgaris On industrial co-products. Algal Res. v.1(1), p. 40-48, (2012)

O'GRADY, J.; MORGAN J.A. Heterotrophic growth and lipid production of Chlorella protothecoides on glycerol Bioprocess Biosyst. Eng., v. 34, p. 121-125, 2010.

PATIL, P.D.; GUDE, V.G.; MANNARSWAMY, A.; DENG, S.; COOKE, P.; MUNSONMCGEE, S.; RHODES, I.; LAMMERS P.; NIRMALAKHANDAN N. Optimization of direct conversion of wet algae to biodiesel under supercritical methanol conditions. Bioresour. Technol., v.102, p. 118-122, 2011.

PEREZ-GARCIA, O.; ESCALANTE, F.M.E.; DE-BASHAN, L.E; BASHAN Y. Heterotrophic cultures of microalgae: metabolism and potential products. Water Res., v. 45, p. 11-36, 2011.

PITTMAN, J.K.; DEAN, A.P.; OSUNDEKO, O. The potential of sustainable algal biofuel production using wastewater resources Bioresour. Technol., 102, p. 17-25, 201.,

RAI,P.M.; NIGAM, S.; SHARMA. Response of growth and fatty acid compositions of Chlorella pyrenoidosa under mixotrophic cultivation with acetate and glycerol for bioenergy application. Biomass Bioen., v. 58, p. 251-257, 2013.

RAMANNA, L.; GULDHE,A.; , I.; BUX,The optimization of biomass and lipid yields of Chlorella sorokiniana when using wastewater supplemented with different nitrogen sources. Biores. Techn., In Press, available online 27 March 2014. 